\title{
A Research on Quality Evaluation Method for Thematic Monitoring Results
}

\author{
Chen Chunxi ${ }^{1}$, Zhang Jixian ${ }^{1}$, Zhao Haitao ${ }^{1}$, Li Chang ${ }^{1}$, Zhao Ying ${ }^{1}$ \\ ${ }^{1}$ National Quality Inspection and Testing Center For Surveying and Mapping, e-mail:33360883@qq.com, \\ phone:13810700345, regular mailing address:28 Lianhuachi West Road, Haidian District, Beijing, China
}

\begin{abstract}
KEY WORDS: geographical conditions monitoring, thematic monitoring results ,quality evaluation, evaluation objects, quality elements, quality sub-elements
\end{abstract}

\begin{abstract}
:
The geographical condition is a very important component of a country's national condition, and geographical conditions monitoring (GCM) has been a great concern to the Chinese government. In accordance with application areas, GCM can be divided into fundamental monitoring, thematic monitoring, and disaster monitoring. Thematic monitoring is a special type of designated subject monitoring that concerns the public or the government. This paper mainly discusses the quality evaluating method of thematic monitoring results (TMRs). Based on analysis, referring to GB/T 24356-2009 "Quality Inspection and Acceptance of Surveying and Mapping Achievements", TMRs data Including monitoring data results, analysis and evaluation results, map results and monitoring report results. The operability of the quality evaluation model is illustrated by a case study of the quality inspection of urban geographic national condition monitoring.
\end{abstract}

\section{INTRODUCTION}

The results of thematic geographic condition monitoring (TMRs) are based on spatial data. According to the requirements of different projects, spatial data are analyzed and modeled to form thematic data sets, statistical analysis results, map results and thematic monitoring reports. From the tracking statistics year by year, we can get the past, the present situation and the forecast of the future development. The results of thematic geographic and national conditions monitoring are the basis for the decision-making of the government and administrative departments, which must be guaranteed to be accurate and reliable. We have carried out inspection and acceptance of the quality of the project results. How to ensure the unification of quality evaluation content and quality evaluation scale, the project team carried out research, put forward the quality evaluation model of thematic results, and applied the model to carry out a pilot evaluation of the thematic results of urban geographic national condition monitoring in a certain year.

\section{CHARACTERISTICS OF THEMATIC OUTCOMES}

Through the comparative analysis of the basic and thematic monitoring results, the characteristics of the thematic results are as follows.

\subsection{There are many kinds of data sources.}

TMRs originally include geographic information data sources, thematic data sources and various image data sources.

\subsection{The process of production analysis is complex.}

The thematic monitoring of geographical and national conditions includes six topics: first, monitoring of land and space development; second, monitoring of resource conservation and utilization; third, monitoring of ecological environment protection; fourth, monitoring of urbanization development; fifth, monitoring of major national strategies and overall regional development; and sixth, other monitoring. The analytical models for each topic are different.

\subsection{The results are manifested in various forms.}

MRs include data sets in GDB format, analysis and evaluation results, multi-temporal and multi-source image results, thematic map results in map category, and report results and statistical results in document category.

\subsection{The results vary greatly.}

On the one hand, the amount of data for each topic varies. When the number of thematic datasets is small, there are thousands of elements and hundreds of thousands of elements. On the other hand, the degree of specialization of thematic achievements is high. In addition to traditional surveying and mapping disciplines, it will also involve the integration of humanities, ecological environment and urban development. As a quality inspector, it is very difficult to fully grasp the characteristics of other disciplines and the calculation model of data.

\section{RESEARCH EMPHASIS}

The research emphasis of quality evaluation of TMRs is to construct quality evaluation model, including inspection object, inspection content, sampling method, quality evaluation model, quality evaluation system and quality evaluation method.

\subsection{Object of inspection}

The basic objects of TMRs inspection and quality evaluation include TMRs data set, analysis and evaluation results, Graphic products and TMRs Reports.

\subsection{TMRs Inspection contents}

TMRs Inspection contents See Table 1. 


\begin{tabular}{|c|c|c|}
\hline $\begin{array}{l}\text { Quality } \\
\text { element }\end{array}$ & $\begin{array}{c}\text { quality } \\
\text { Subelement }\end{array}$ & Inspection contents \\
\hline \multirow{4}{*}{$\begin{array}{c}\text { TMRs } \\
\text { data set }\end{array}$} & $\begin{array}{l}\text { Spatial } \\
\text { Reference } \\
\text { System }\end{array}$ & $\begin{array}{l}\text { Check whether the } \\
\text { coordinate system, } \\
\text { elevation datum and } \\
\text { projection parameters } \\
\text { meet the requirements }\end{array}$ \\
\hline & $\begin{array}{c}\text { Logical } \\
\text { Consistency }\end{array}$ & $\begin{array}{l}\text { Check that file naming, } \\
\text { data format, data } \\
\text { organization, data set } \\
\text { (layer) definition, and } \\
\text { attribute item definition } \\
\text { meet the requirements }\end{array}$ \\
\hline & Correctness & $\begin{array}{l}\text { 1. Check whether the } \\
\text { use of data sources } \\
\text { meets the requirements } \\
\text { 2. Check the correctness } \\
\text { of the location of } \\
\text { elements } \\
\text { 3. Check the correctness } \\
\text { of attribute values of } \\
\text { elements } \\
\text { 4. Check the correctness } \\
\text { of element topology }\end{array}$ \\
\hline & $\begin{array}{l}\text { Completene } \\
\text { ss }\end{array}$ & $\begin{array}{l}\text { Check whether elements } \\
\text { are redundant or } \\
\text { missing }\end{array}$ \\
\hline \multirow{3}{*}{$\begin{array}{l}\text { Analysis } \\
\text { and } \\
\text { evaluation } \\
\text { results }\end{array}$} & $\begin{array}{c}\text { Logical } \\
\text { Consistency }\end{array}$ & $\begin{array}{l}\text { Check file naming, data } \\
\text { format, and data } \\
\text { organization for } \\
\text { compliance }\end{array}$ \\
\hline & Correctness & $\begin{array}{l}\text { 1. Check whether the } \\
\text { units of statistical } \\
\text { measurement and the } \\
\text { reserved digits of } \\
\text { decimal points meet the } \\
\text { requirements. } \\
\text { 2. Check the correctness } \\
\text { of data calculation } \\
\text { 3. Check the } \\
\text { consistency between } \\
\text { statistical results and } \\
\text { monitoring data }\end{array}$ \\
\hline & $\begin{array}{l}\text { Completene } \\
\text { ss }\end{array}$ & $\begin{array}{l}\text { Check whether the data } \\
\text { is redundant or missing }\end{array}$ \\
\hline $\begin{array}{l}\text { Graphic } \\
\text { products }\end{array}$ & $\begin{array}{c}\text { Logical } \\
\text { Consistency }\end{array}$ & $\begin{array}{lr}\text { Check file naming, data } \\
\text { format, and data } \\
\text { organization } \\
\text { compliance }\end{array}$ \\
\hline
\end{tabular}

\begin{tabular}{|c|c|c|}
\hline & $\begin{array}{l}\text { Main graph } \\
\text { quality }\end{array}$ & $\begin{array}{l}\text { 1. Check the } \\
\text { applicability and } \\
\text { correctness of the main } \\
\text { map content } \\
\text { 2. Check the correctness } \\
\text { and rationality of the } \\
\text { elements, notes and } \\
\text { symbols in the main } \\
\text { graph } \\
\text { 3. Check the } \\
\text { consistency of statistical } \\
\text { data, monitoring data } \\
\text { and statistical data in } \\
\text { the main map. }\end{array}$ \\
\hline & $\begin{array}{l}\text { Affiliated } \\
\text { quality }\end{array}$ & $\begin{array}{l}\text { 1. Check the correctness } \\
\text { of the attached figures } \\
\text { and tables, the } \\
\text { standardization of the } \\
\text { text description and the } \\
\text { rationality of the layout. } \\
\text { 2. Check the correctness } \\
\text { and standardization of } \\
\text { the name, legend, scale } \\
\text { and outline decoration } \\
\text { of drawings } \\
3 \text {. Check the } \\
\text { consistency of the } \\
\text { figures in the attached } \\
\text { tables with the } \\
\text { monitoring data and } \\
\text { statistical data. }\end{array}$ \\
\hline \multirow[b]{3}{*}{$\begin{array}{l}\text { TMRs } \\
\text { Report }\end{array}$} & $\begin{array}{c}\text { Completene } \\
\text { ss }\end{array}$ & $\begin{array}{l}\text { Check the integrity of } \\
\text { the monitoring report }\end{array}$ \\
\hline & $\begin{array}{l}\text { Normalizati } \\
\text { on }\end{array}$ & $\begin{array}{l}\text { Inspection of the } \\
\text { normative content of } \\
\text { monitoring reports }\end{array}$ \\
\hline & Uniformity & $\begin{array}{l}\text { Check the consistency } \\
\text { of statistical data, } \\
\text { illustrations, tables and } \\
\text { monitoring data, } \\
\text { statistical data and } \\
\text { drawings in monitoring } \\
\text { reports }\end{array}$ \\
\hline
\end{tabular}

Table 1. TMRs Inspection contents

\subsection{Sampling method}

TMRs should be checked as a whole. TMRs data set, analysis and evaluation results and Graphic products can be carried out according to the situation, and the data with a ratio of not less than $10 \%$ can be extracted in units of administrative divisions, regions, element sets and ranges.

\subsection{Quality Evaluation Model}

Because the results of each quality element of the project results are cross-referenced, the quality evaluation model is to evaluate the project results as a whole. Among them, TMRs data set is the basis of analysis and evaluation results, Graphic products and TMRs Reports, with a large proportion of weight. The 
consistency of the data of four quality elements in the checking content needs to be checked emphatically.

\begin{tabular}{|c|c|c|c|}
\hline $\begin{array}{l}\text { Quality } \\
\text { element }\end{array}$ & weight & $\begin{array}{c}\text { Quality } \\
\text { Subelement }\end{array}$ & weight \\
\hline \multirow{4}{*}{$\begin{array}{c}\text { TMRs } \\
\text { data set }\end{array}$} & \multirow{4}{*}{0.4} & $\begin{array}{c}\text { Spatial } \\
\text { Reference } \\
\text { System }\end{array}$ & 0.1 \\
\hline & & $\begin{array}{c}\text { Logical } \\
\text { Consistency }\end{array}$ & 0.1 \\
\hline & & Correctness & 0.5 \\
\hline & & $\begin{array}{c}\text { Completene } \\
\text { SS }\end{array}$ & 0.3 \\
\hline \multirow{3}{*}{$\begin{array}{l}\text { Analysis } \\
\text { and } \\
\text { evaluatio } \\
n \text { results }\end{array}$} & \multirow{3}{*}{0.2} & $\begin{array}{c}\text { Logical } \\
\text { Consistency }\end{array}$ & 0.1 \\
\hline & & Correctness & 0.6 \\
\hline & & $\begin{array}{c}\text { Completene } \\
\text { ss }\end{array}$ & 0.3 \\
\hline \multirow{3}{*}{$\begin{array}{l}\text { Graphic } \\
\text { products }\end{array}$} & \multirow{3}{*}{0.2} & $\begin{array}{c}\text { Logical } \\
\text { Consistency }\end{array}$ & 0.1 \\
\hline & & $\begin{array}{c}\text { Main graph } \\
\text { quality }\end{array}$ & 0.6 \\
\hline & & $\begin{array}{c}\text { Affiliated } \\
\text { quality }\end{array}$ & 0.3 \\
\hline \multirow{3}{*}{$\begin{array}{l}\text { TMRs } \\
\text { Report }\end{array}$} & \multirow{3}{*}{0.2} & $\begin{array}{l}\text { Completene } \\
\text { ss }\end{array}$ & 0.3 \\
\hline & & $\begin{array}{l}\text { Normalizati } \\
\text { on }\end{array}$ & 0.3 \\
\hline & & Uniformity & 0.4 \\
\hline
\end{tabular}

Table 2. Quality Elements and Weights of Thematic Outcomes

\subsection{Quality Evaluation System}

The evaluation system and quality evaluation method are derived from the quality inspection and acceptance of GB/T 24356-2009 surveying and mapping results. According to the severity of the problem detected, it is judged which type belongs to $\mathrm{A}, \mathrm{B}, \mathrm{C}$ and $\mathrm{D}$, and the corresponding score is deducted.

\begin{tabular}{|c|c|c|}
\hline $\begin{array}{c}\text { Types of } \\
\text { errors and } \\
\text { omissions }\end{array}$ & $\begin{array}{c}\text { deduction } \\
\text { criteria }\end{array}$ & classification principles \\
\hline A & 42 score & $\begin{array}{c}\text { An error or omission of an } \\
\text { extremely important inspection } \\
\text { item or a very serious error or } \\
\text { omission of an inspection item }\end{array}$ \\
\hline B & $12 /$ score & $\begin{array}{c}\text { Mistakes and omissions of } \\
\text { important inspection items or } \\
\text { serious omissions of inspection } \\
\text { items }\end{array}$ \\
\hline C & $4 / t$ score & $\begin{array}{c}\text { Mistakes and omissions of the } \\
\text { more important items or of the } \\
\text { more serious items }\end{array}$ \\
\hline D & $1 /$ t score & $\begin{array}{c}\text { Minor errors and omissions in } \\
\text { general checks }\end{array}$ \\
\hline
\end{tabular}

$\mathrm{t}$ refers to the adjustment coefficient, which is generally taken as 1 . When adjustment is needed, it should be approved by the production principal.

Table 3. Classification and Evaluation Table for Mistakes and Leaks of Quality Elements

\subsection{Quality assessment method}

1.Scoring method of mass sub-elements according to formula (1)
$\mathrm{S} 2=100-\{\mathrm{a} 1 *(12 / \mathrm{t})+\mathrm{a} 2 *(4 / \mathrm{t})+\mathrm{a} 3 *(1 / \mathrm{t})\}$

S2- - Score Value of Mass Subelements;

a1- - Number of errors and omissions in Class B;

a2- - Number of errors and omissions in Class C;

a3 - - Number of errors and omissions in Class D;

t-—Adjustment coefficient。

2.Quality Element Scoring Method According to Formula (2)

$S_{1}=\sum_{i=1}^{n}\left(S_{2 i} \times p_{i}\right)$

S1-—Score Value of Mass Elements;

S2i- - Score Value of the First Mass Subelement in Mass Elements;

pi-C The Weight of the First Mass Subelement in Mass Elements;

$\mathrm{n}$ - - Number of Mass Subelements in Mass Elements。

3. Grading of achievement quality according to formula (3)

$S=\sum_{i=1}^{n}\left(S_{1 i} \times p_{i}\right)$

$\mathrm{S}$ - - Outcome Score Value;

$\mathrm{S} 1 \mathrm{i}-$ - Score value of the first mass element;

pi-—The i Quality Element Weight;

$\mathrm{n}$ - - Number of quality elements contained in the results 。

4.The quality evaluation of thematic achievements can be divided into excellent, good, qualified and unqualified evaluation systems.

\begin{tabular}{|c|c|}
\hline Quality score & Quality grade \\
\hline 90 points $<=\mathrm{S}<=100$ points & excellent \\
\hline 75 points $<=\mathrm{S}<90$ points & good \\
\hline 60 points $<=\mathrm{S}<75$ points & qualified \\
\hline $\mathrm{S}<60$ points & Unqualified \\
\hline
\end{tabular}

Table 4 Grade of Quality Assessment of Thematic Achievements

\section{CASE ANALYSIS}

Taking the special topic of urban geographic national condition monitoring as an example, this paper analyses how to carry out quality evaluation of a special geographic national condition monitoring result.

The monitoring of urban geography and national conditions is mainly to carry out comprehensive monitoring of urban space, the level of basic public services, the monitoring of urban comprehensive transportation network, the monitoring of spatial pattern changes of urban agglomerations, the relocation and transformation of old industrial zones in urban areas and the thematic monitoring of sponge cities, which are suitable for the needs of new-type urbanization construction. Its results can provide practical data support and decision-making basis for the formulation of new urbanization policies.

\section{1 sampling}

4.1.1 The monitoring results of urban geographic conditions include:

1. 108 urban comprehensive monitoring data sets; 4 typical urban agglomeration monitoring data sets; 4 sponge-type urban data sets; 21 urban old industrial areas monitoring data sets.

2. Four analysis and evaluation results; the comprehensive analysis and evaluation results of urban space, the analysis and evaluation results of spatial pattern of urban agglomerations; the analysis and evaluation results of the implementation effect of typical regional construction of sponge-type cities; the analysis and evaluation results of the implementation of relocation and transformation of old industrial zones. 
3. 108 urban comprehensive monitoring maps; 4 typical urban agglomeration monitoring maps; 4 sponge-type urban maps; 21 urban old industrial zones maps.

4. Four monitoring reports: comprehensive monitoring report of urban space; monitoring report of spatial pattern change of urban agglomeration; monitoring report of implementation effect of typical regional construction of sponge city; monitoring report of relocation and transformation of old industrial zone.

4.1.2 According to the 3.3 sampling method, the sampling results are as follows:

1. 11 urban comprehensive monitoring data sets; 4 typical urban agglomeration monitoring data sets; 4 sponge-type urban data sets; 3 urban old industrial areas monitoring data sets.

2. Overall examination of the results of four analysis and evaluation.

3. 11 urban comprehensive monitoring maps; 4 typical urban agglomeration monitoring maps; 4 sponge-type urban maps; 3 old industrial district maps of urban areas.

\subsection{Check the main problem description}

Four quality elements, TMRs data set, analysis and evaluation results, Graphic products and TMRs Reports were examined. The main problems are as follows:

1. TMRs data set

(1) Incomplete data integration and lack of urban monitoring data sets in 2 provinces;

(2) The organizational structure of some data sets is inconsistent with the requirements of the design document.

2. Analysis of evaluation results

Individual tables are missing from the analysis and evaluation results (i.e. statistical summary tables).

3. Graphic products

(1) A Graphic product is not standardized, such as missing scale; (2) The data format and file naming of some drawings are inconsistent with the requirements of the design book;

4. TMRs Reports

(1) Individual statistical values are inconsistent with the results of analysis and evaluation;

(2) A small amount of written expression is inconsistent with the results of tables, analysis and evaluation;

(3) Individual errors in illustrations and tables.

\subsection{Quality evaluation}

According to 4.2 inspection results and 3.6 quality evaluation formula, the evaluation is shown in table $\mathrm{x}$ below. The final total score is 94.7, and the quality grade of the result is excellent.

\begin{tabular}{|c|c|c|c|c|}
\hline $\begin{array}{l}\text { Quality } \\
\text { element }\end{array}$ & $\begin{array}{c}\text { Quality } \\
\text { Subeleme } \\
\text { nt }\end{array}$ & $\begin{array}{l}\text { Deducti } \\
\text { on }\end{array}$ & $\begin{array}{l}\text { Individu } \\
\text { al score }\end{array}$ & $\begin{array}{c}\text { Achievemen } \\
\text { t score }\end{array}$ \\
\hline \multirow{4}{*}{$\begin{array}{c}\text { TMRs } \\
\text { data } \\
\text { Set } \\
(0.4)\end{array}$} & $\begin{array}{c}\text { Spatial } \\
\text { Reference } \\
\text { System }\end{array}$ & - & \multirow{4}{*}{92.8} & \multirow{5}{*}{94.7} \\
\hline & $\begin{array}{c}\text { Logical } \\
\text { Consisten } \\
\text { cy }\end{array}$ & - & & \\
\hline & $\begin{array}{c}\text { Correctne } \\
\text { ss }\end{array}$ & - & & \\
\hline & $\begin{array}{c}\text { Complete } \\
\text { ness }\end{array}$ & $2 \mathrm{~B}$ & & \\
\hline $\begin{array}{c}\text { Analysis } \\
\text { and } \\
\text { evaluati }\end{array}$ & $\begin{array}{c}\text { Logical } \\
\text { Consisten } \\
\text { cy }\end{array}$ & - & 96.4 & \\
\hline
\end{tabular}

\begin{tabular}{|c|c|c|c|}
\hline \multirow{2}{*}{$\begin{array}{l}\text { on } \\
\text { results } \\
(0.2)\end{array}$} & $\begin{array}{c}\text { Correctne } \\
\text { ss }\end{array}$ & - & \\
\hline & $\begin{array}{l}\text { Complete } \\
\text { ness }\end{array}$ & $3 \mathrm{C}$ & \\
\hline \multirow{3}{*}{$\begin{array}{c}\text { Graphic } \\
\text { products } \\
(0.2)\end{array}$} & $\begin{array}{c}\text { Logical } \\
\text { Consisten } \\
\text { cy }\end{array}$ & $3 \mathrm{C}$ & \multirow{3}{*}{97.6} \\
\hline & $\begin{array}{l}\text { Main } \\
\text { graph } \\
\text { quality }\end{array}$ & - & \\
\hline & $\begin{array}{c}\text { Affiliated } \\
\text { quality }\end{array}$ & $1 \mathrm{C}$ & \\
\hline \multirow{3}{*}{$\begin{array}{c}\text { TMRs } \\
\text { Report } \\
(0.2)\end{array}$} & $\begin{array}{c}\text { Complete } \\
\text { ness }\end{array}$ & - & \multirow{3}{*}{94.0} \\
\hline & $\begin{array}{l}\text { Normaliza } \\
\text { tion }\end{array}$ & $1 \mathrm{C}$ & \\
\hline & $\begin{array}{c}\text { Uniformit } \\
\mathrm{y}\end{array}$ & $3 \mathrm{C}$ & \\
\hline
\end{tabular}

Table 5 .Quality Evaluation Table of Urban Geographic Situation Monitoring Achievements

\section{CONCLUSIONS}

TMRs is a new work, and there is no quality evaluation model for such results at present. In this paper, a general quality inspection model of project results is proposed. The model defines the sampling method and unifies the evaluation criteria and criteria. Through the case study of thematic inspection of urban geographic national condition monitoring, it shows that the evaluation model is suitable for thematic results quality inspection. The evaluation results help project organizers to understand the quality of results, help project producers to better improve the quality of thematic results, and effectively guarantee the integrity, standardization and unity of thematic results. The next step is to expand the scope of thematic results inspection and propose more perfect inspection rules to facilitate the better use of quality inspectors.

\section{REFERENCES}

ZHANG Jixian, ZHAI Liang, 2016:Thinking about Normalized Geographical Conditions Monitoring[J].GEOSPATIAL INFORMATION,2016,14(4):1-3.

Li Weisen, 2017:The Geographic Conditions Monitoring Promoting the Transformation and Upgrading of Surveying,Mapping and Geoinformation Industry[J]. GEOMATICS WORLD,2017,24(2):1-6.

GUI Dezhu,LIN Zongjian,Zhang Chengcheng, 2017:Foundation of strengthen the Monitoring of the National Geographic Conditions.[J].Beijing Surveying and mapping,2017(2):133-137.

GB/T 24356-2009, Quality Inspection and Acceptance of Surveying and Mapping Achievements [S] 